\title{
WASTELANDS AS AN OPPORTUNITY FOR MANAGING NAPLES' SUSTAINABLE TRANSITION
}

\begin{abstract}
Circular economy offers new visions of how diversely urban spaces could be inhabited and managed. While the generation and management of waste is being treated through innovative practices, disused industrial, rural, and infrastructural areas are resistant to becoming included in a closed-loop cycle. They, in fact, establish wastelands that need to be completely re-imagined as a precondition for the transition. The fact of shifting the definition of a 'neglected area' into a 'wasteland', in line with the metaphor of urban metabolism, could be of tactical importance for generating alternative policies and practices. In exploring how the transition impacts Naples' urban region, the paper argues that turning wastelands into resources has the double potential of rehabilitating spaces and challenging the governance model in use, overcoming barriers in multiple sectors.
\end{abstract}

Key words: wastescape regeneration, multilevel governance, waste circularity, transition management.

\section{INTRODUCTION}

Circular economy, one of the pillars of sustainable transitions promoted by the EU, suggests new visions of how people should live in urban space and, consequently, how it should be managed. The roots of such mostly conceptual visions are strongly dependent on the powerful metaphor of urban metabolism. It helps not only in the imaging and organising of strategies for the transition process, but also in situating them and completely rethinking the governance model consistent with urban metabolism itself. The metabolisation of such transitions demands deep changes in the dominant practices, policies and ways of thinking, which will in turn call for new knowledge on the part of ordinary people, and different research frameworks and responsibilities on the part of scholars and institutions, respectively.

*Gilda BERRUTI, Maria Federica PALESTINO, University of Naples Federico II, Department of Architecture, via Forno Vecchio 36, 80134 Naples, Italy; e-mails: gberruti@unina.it, palestin@unina.it, ORCIDs: https://orcid.org/0000-0003-1777-4793, https://orcid.org/0000-0002-3709-3728 
The Horizon 2020 research REPAiR, "Resource Management in Peri-urban Areas: Going Beyond Urban Metabolism", promotes the reuse of waste as a resource. In this framework, peri-urban areas have to be reinterpreted as those "transition spaces with some degree of intermingling of urban and rural uses" which characterise urban regions of European cities (Wandl and Magoni, 2017, p. 1).

As for the methodology, the transition management has been adopted in order to examine how to reduce waste flows in peri-urban areas, beginning from the pilot cases of Naples and Amsterdam ${ }^{1}$.

According to the metaphor of urban metabolism, considered as a device to address the transition, urban regions have been interpreted as complex ecosystems. Consistent with this conceptual framework, one of the first steps of the REPAiR strategy consists of deliberately turning a definition of a 'neglected area' into a 'wasteland', in order to emphasise the shift from the socio-technical regime of the linear economy, where the adjective neglected refers to the end of the Fordist domain, to the socio-technical regime of the circular economy, where the manner of regulating the metabolism of waste is crucial. Since this shift has been generating alternative narratives and different public discourses and images, we have been exploring policy instruments and practices that fit the new vision.

According to the new narrative, waste flows in peri-urban areas have to be tightly related to the entanglement between solid waste and wastelands. The latter should be considered as ruins germinated from the shrinkage or even disappearance of past land uses such as industrial, rural, infrastructural and so on, with the consequent degradation into wastelands.

In the urban region between Naples, Caserta and Salerno, waste has often been stock-piled or even concealed in peri-urban areas with the effect of transforming abandoned or soon to be abandoned open spaces and land into wastelands. The urban region has been nicknamed the "Land of Fires" since 2003, due to the malpractice by organised crime of burning waste stocked illicitly. In particular, the Land of Fires is the consequence of a previous fifteen-year-old regional waste emergency (Cantoni, 2016). Due to the weak territorial control on the part of institutions, the instances of arson, combined with the effects of the waste management crisis, and other endemic problems affecting the region since the 1960s, such as poverty, low schooling, unregulation (De Leo and Palestino, 2017) and nepotism (di Gennaro, 2014; Corona and Sciarrone, 2012), not only

\footnotetext{
${ }^{1}$ The academic partners of REPAiR (Grant Agreement no. 688920), together with the Joint Research Center of the EU, and several public institutions and public/private companies in the field of waste management, consist of universities and research institutes from Delft (the Netherlands), Naples (Italy), Hamburg (Germany), Łódź (Poland), Pécs (Hungary), and Ghent (Belgium). The Naples REPAiR team is composed of researchers from the Department of Architecture of the Federico II University and officials from the Campania Regional Authority, while the mayor of Naples is in the user board. See: http://h2020repair.eu/.
} 
caused toxic conflagration (Musmeci et al., 2016), but even the overproduction of urban informality.

The resulting wastelands include: stretches of agricultural land housing unauthorised buildings; portions of abandoned heritage sites; polluted sites under designated state tutorship; housing or productive facilities confiscated by the state from criminal organisations, etc. (Berruti and Palestino, 2018; Berruti, 2018). This is why, following the socio-ecological disaster of the 'Land of Fires', the regional plan of the Caserta Province termed an area of approx. 5000 ha of critical land with accumulations of waste as negated land (Provincia di Caserta, 2012).

As a consequence, the quality of life is low and inhabitants do not trust the institutions, and even struggle against them in order to defend their right to urban environments (Berruti and Palestino, 2020; Kaika and Swyngedouwn, 2011).

Moreover, when many wastelands compound the effect of bringing waste to the foreground of cities, the result is the proliferation of wastescapes (Geldermans et al., 2017; Amenta and van Timmeren, 2018). Such wastescapes even spill over the administrative borders of individual municipalities, thus involving different communities and institutions and requiring complex multilevel governance. They need, therefore, to be completely re-imagined, re-framed and re-organised, a fact which is a precondition for their sustainable transition.

This is why one of the most important challenges for REPAiR-Naples is the promotion of a common understanding of how to include not only waste and waste flows, but also wastelands, in a closed-loop production cycle.

In exploring how the transition toward sustainability is affecting social actors, decision models, and formal and informal practices in the urban region of Naples, the paper focuses on how turning wastelands into resources has the double potential of rehabilitating urban spaces and challenging the governance model in use. In so doing the framework of transition management offers an inspiring methodology for planning how to reduce, recycle and regenerate waste and wastelands in peri-urban Naples.

\section{THE TRANSITION TOWARDS SUSTAINABILITY}

The framing of environmental problems triggers complex societal challenges that require socio-technical transitions and modify the workings of territorial systems. Contemporary transitions towards sustainability can be considered as specific processes of long-term, multilevel and multiphase change that happen in complex and adaptive systems such as cities and urban regions. As a consequence, sustainable transitions work as multi-actor processes involving firms, industries, policy makers, and politicians, but also consumers, civil society, and researchers. It is 
important to underline that, while focused on the environment, transitions towards sustainability are closely related to collective goods (Geels, 2011).

Being an open-ended process aimed at reframing problems through social learning and experimenting, the transition management approach can be successfully adapted both for supporting policies and engaging actors in order to find innovative solutions. As a matter of fact, its recent urban turn (Wittmayer and Loorbach, 2016) has provided site-specific applications in domains such as energy, water, mobility, and climate change, since the challenges in applying circular economy are frequently located in cities, towns, and neighbourhoods. Furthermore, these applications of transition management describe governance processes where frontrunners among policy-makers, scientists, business, and the society are asked to share their understanding of complex challenges. Thus, they help researchers analyse urban sustainability, supporting shared visions and strategies extensively, and experiment with social innovations (Loorbach, 2010; Wittmayer and Loorbach, 2016).

It is important to add that the transition management is conceived as a kind of selective participative setting that works as an iterative cycle of mutual learning. Thanks to ad hoc networks of pivot stakeholders coming from different backgrounds, it develops a plural discourse which is aimed at guiding sustainable transitions. Given the cyclical nature of the transition management framework, strategic level activities are followed by tactical and operational phases, while the cycle itself is closed by means of the resulting appropriate reflexive measures.

The aim of the strategic activities is to direct the public discourse and the related narrative through long-term visions. It is necessary to create an arena of frontrunners with different backgrounds during this stage in order to imagine a future perspective, together with transition pathways.

Tactical activities have to be built in the mid and the long terms, dividing the public discourse into steps, preparing the transition agenda, and analysing gaps between different scenarios. Consistent with this 'agenda setting' stage, tactics to explore and specific pathways can be further developed by means of negotiation and collaboration among actors. Operational activities, working in the short term, are oriented towards sharing those specific needs coming from practice, projects, and experiments. This stage is based on "activating" communities and anchoring ideas from below. Reflexive activities offer the basis for monitoring the previous three levels, where the focus is on how to support and enable societal learning processes.

When all four levels are embedded in urban contexts, the related actions are fulfilled through experimentation at the so-called Urban Transition Labs, which are inspired by the Living Labs approach. Living Labs are defined as "user-centered, open innovation ecosystems based on a systematic user co-creation approach in public-private-people partnership, integrating research and innovation processes in real life communities and settings" (ENoLL, 2013; Concilio, 2016). In Living 
Labs, the innovation process is ensured by co-creation activities (Steen and van Bueren, 2017) enacted by the presence of several stakeholders at the same time in the same place, working to identify challenges and co-design feasible solutions and strategies. The involvement in the process of different stakeholders is crucial for the delivery of a successful result.

\section{FOSTERING WASTESCAPE REGENERATION IN PERI-URBAN NAPLES}

The focus area of REPAiR Naples includes eleven municipalities, going from the eastern city to the town of Acerra, making up a peri-urban area of 519,425 inhabitants and 164.6 square kilometres where different wastelands and waste flows intersect. We chose this vast area and a smaller sample area, mainly due to the following reasons: it is an area strongly affected by the fifteen-year-old regional waste emergency and socio-ecological disaster known as the Land of Fires (Armiero, 2014; Palestino, 2015), the high percentage and variety of wastelands, and its location within the administrative boundaries of the regional waste management system.

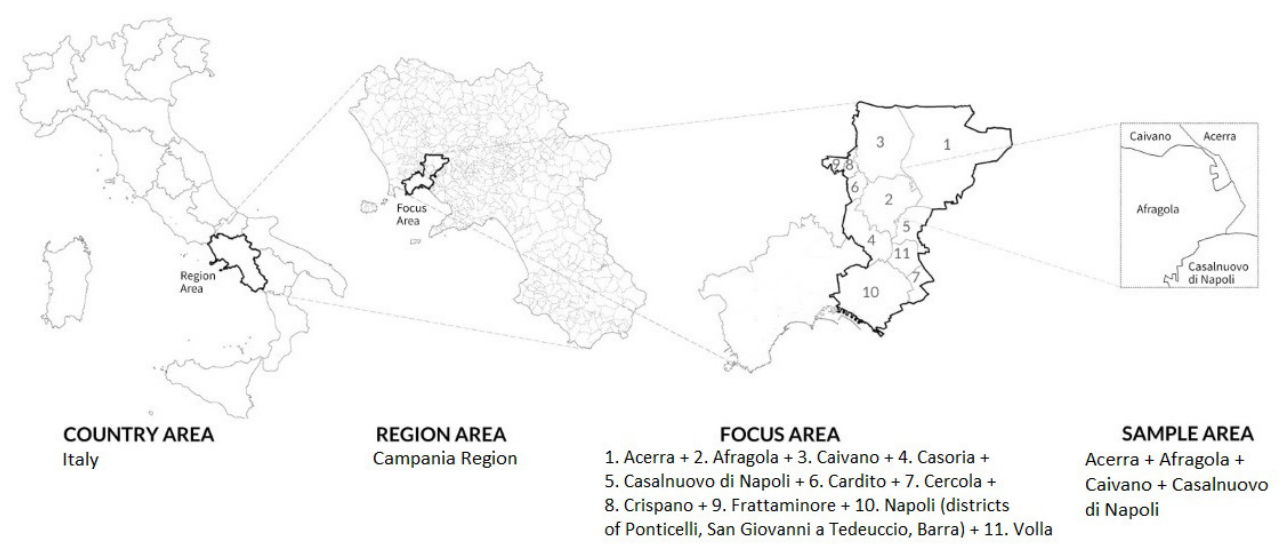

Fig. 1. Naples' Focus and sample area in the REPAiR Project Source: Geldermans et al., 2018, fig. 2, p. 24

In line with the transition management model, we organised the research by means of an 'orienting phase' where the strategy of looking at waste as a resource was defined. In this perspective, redefining the abandonment of places provided the agenda for regenerating them with a new perspective, and using the provided funding. Thus, a focus on wastescapes has supported a vision which was strong enough to allow the 
introduction of circular economy principles both through designing new measures and policies, and involving distrustful citizens in taking care of peri-urban spaces. At the beginning, the arena of the frontrunners was composed by the research team from the Department of Architecture, Federico II University of Naples, several officials of the Campania Region belonging to the Departments of Environment, Planning and Agriculture, and selected user-board members from the City of Naples. Citizens as representatives of local associations and movements were added later.

The agenda setting was supported by interviews with politicians and officials aimed at analysing the governance of waste in the focus area and by institutional meetings where shared knowledge on the working of the waste management system and the related challenges was collected. Representatives of regional, metropolitan and municipal governments and policy makers, waste management administrators, local company representatives all joined those meetings. In directing them, the research team worked hard to set the agenda, starting from the outcomes of this stage. Later, with the organisation of peri-urban living labs (PULLs) the activating stage began. Apart from institutional actors and companies, social organisations and active citizens were also involved in the experiments of innovation.

PULLs have mainly focused on wastescapes and eco-innovative solutions. First, participants identified critical wastescapes in the focus area, located them on the map, and collectively updated the map and its legend ${ }^{2}$. Next, they framed solutions for wastescapes. Participants were organised into three worktables, each focused on a territorial project to be fulfilled together with the aim of discovering the proper eco-innovative solutions to the investigated wastescapes. Later, proposals coming from previous workshops were analysed and each territorial project was transformed into action (Amenta et al., 2019). The current possibility of funding the proposed actions was explored, as well as actors' commitment to support them.

The operational activities included the co-designing of actions aimed at solving problems of abandonment related to wastescapes, and the attribution of specific responsibilities to the actors involved in Living Labs. At this stage, some negotiations between public administrators and inhabitants were conducted by the REPAiR team in order to reveal previous conflicts or solve those which emerged during their interactions.

Actions proposed during Living Labs provided the base for drawing eco-innovative solutions, also by means of improvements made by the research team, through the involvement of public sector officials and companies, carrying out part of the reflexive activities. This step was mainly aimed at transforming them from site-specific to generally transferable, and indicating aspects of innovation.

The activation phase was planned as the result of a further learning process in which collaborative decisions should be taken by means of a geo-design planning support system that was currently under investigation by the research team.

\footnotetext{
${ }^{2}$ For information on maps of critical landscapes in the focus area, see Geldermans et al. (2018).
} 


\section{OVERCOMING THE GAP TOWARDS A SUSTAINABLE TRANSITION}

As indicated by the transition management process applied to the metabolism of waste in Naples, the first important step towards a transition consisted of overcoming the current provisional nature of the waste management system, through a partial enforcement of the regional law on waste management (R.L. no. 14/2016). On the one hand, though the Campania Region has made circular economy a leading principle in the law on the waste management, the same principle seems to be neglected in policy implementation processes. On the other hand, municipalities are interested in maintaining benefits and relationships coming from the waste management system developed during the environmental emergency, often relying on companies selected through political nepotism. In so doing, the fact of preserving the waste management existing status quo ends up responding to decision-makers and organised crime stakes, even if for different reasons. The former for ensuring the pre-existing policy networks, the latter for defending the self-activating arrangement in politics and the economy in which organised crime is involved. Moreover, the Metropolitan City of Naples, which might have exerted a connective role in the transition stage, was erroneously excluded from the waste management.

Intra-institutional difficulties in overcoming sectorial policies, together with the lack of shared knowledge about waste management among institutions and among citizens also contribute to hindering the application of circular economy principles (Obersteg et al., 2019). In addition, social attitudes also play a role, through suspicions about the quality of waste, and the consequential stigmatisation and distrust that prevent innovation in policies and the development of new economies. For instance, companies managing composting plants do not use organic waste coming from Campania because of its supposed (and often actual) poor quality; local communities fight against any proposal concerning waste coming from a higher level of administration, even if they are concerned about the location of a new composting plant that could be effective in resolving the organic waste management system at a local scale ${ }^{3}$.

As for wastescapes, there are some interesting experiences of recovery and re-appropriation in the metropolitan area of Naples that require but do not receive the appropriate support from institutions. In addition to governance aspects, the capability of including wastescapes regeneration in an overall vision covering peri-urban areas and defining their potentialities has to be enhanced.

\footnotetext{
${ }^{3}$ Actually, in the region, a high percentage of organic waste is displaced in Northern Italy's plants. The lack of composting plants carries the risk of creating a new emergency concerning organic waste.
} 


\section{CONCLUSIONS}

In the metropolitan area of Naples, circular economy currently works mainly as a rhetorical argument that is still hard to apply through policies, mainly due to ineffective sectorial planning and to difficulties in making urban metabolism work. Therefore, clear suggestions appear for how to enhance circular policies and regenerate circular landscapes.

First, PULLs function as useful environments for driving all the actors involved in the process to co-design site specific policies, while unravelling past conflicts and issues. Second, people and companies are a reliable source of creative actions and entrepreneurial initiatives on wastelands and waste flows. Third, public officials have to overcome sectorial and departmental barriers within the bureaucratic apparatus in order to apply their theoretical arguments on circular economy to real and effective policies, while seizing the innovations coming from local contexts. As a consequence, we recommend the adoption of a multilevel and cross-sectorial governance as the right way for designing and implementing circular policies.

As for wastelands, the transition management approach revealed itself useful for designing eco-innovative strategies and solutions and for rethinking new uses and practices for their regeneration. Such regeneration implies, on the one hand, that wastelands have to be treated as complex groupings of people and places, and, on the other, that, since landscapes do not follow administrative borders, a synergy between institutions is needed to create bridges between different actors and centres of responsibility. Innovations always require the courage to enact change, in multiple sectors (legal, political, economic, social, environmental, and technological) and overcoming barriers. Among these innovations we would stress the need for governance of wastescapes regeneration that has to be designed and implemented in order to effectively re-introduce wastescapes into urban metabolism.

\section{REFERENCES}

AMENTA, L. and VAN TIMMEREN, A. (2018), 'Beyond Wastescapes: Towards Circular Landscapes. Addressing the Spatial Dimension of Circularity through the regeneration of Wastescapes', Sustainability, 10 (12), p. 4740. https://doi.org/10.3390/su10124740

AMENTA, L., ATTADEMO, A., REMØY, H., BERRUTI, G., CERRETA, M., FORMATO, E., PALESTINO, M.F. and RUSSO, M. (2019), 'Managing the Transition towards Circular Metabolism: Living Labs as a Co-Creation Approach', Urban Planning, 4 (3), pp. 5-18. https://doi. org/10.17645/up.v4i3.2170

ARMIERO, M. (2014), 'Garbage under the Volcano: The Waste Crisis in Campania and the Struggles for Environmental Justice', [in:] ARMIERO, M. and SEDREZ, L. (eds.), A History of Environmentalism, London: Bloomsbury, pp. 167-184. 
BERRUTI, G. (2018), 'Wastescape regeneration as a chance for circular peri-urban processes. Reporting from the urban region of Naples, Urbanistica, 162, pp. 128-137.

BERRUTI, G. and PALESTINO, M.F. (2018), 'Looking from Italy at the fertile boundary between formality and informality', Crios, 15, pp. 27-40. https://doi.org/10.3280/CRIOS2018-015003

BERRUTI, G. and PALESTINO, M.F. (2019), 'Contested land and blurred rights in the Land of Fires (Italy)', International Planning Studies, 25 (3), pp. 277-288. https://doi.org/10.1080/135 63475.2019 .1584551

CANTONI, R. (2016), 'The waste crisis in Campania, South Italy: a historical perspective on an epidemiological controversy', Endeavour, 40 (2), pp. 102-113. https://doi.org/10.1016/j.endeavour.2016.03.003

CONCILIO, G. (2016), 'Urban Living Labs: Opportunities in and for Planning', [in:] CONCILIO, G. and RIZZO, F. (eds.), Human Smart Cities. Rethinking the Interplay between Design and Planning, Switzerland: Springer, pp. 21-40. https://doi.org/10.1007/978-3-319-33024-2_2

CORONA, G. and SCIARRONE, R. (2012), 'Il paesaggio delle ecocamorre', Meridiana, 73-74, pp. 13-35.

DE LEO, D. and PALESTINO, M.F. (2017), 'S-regulation matters', [in:] BALDUCCI, A., FEDELI, V. and CURCI, F. (eds.), Post-metropolitan Territories. Looking for a New Urbanity, Routledge, London, New York, pp. 274-280. https://doi.org/10.4324/9781315625300-15

DI GENNARO, A. (2014), 'Per una storia dell'ecosistema metropolitano di Napoli', Meridiana, 80, pp. $105-124$.

ENoLL (2013), ENoLL Living Labs, http://www.openlivinglabs.eu/livinglabs [accessed on: 15.05.2019].

GEELS, F.W. (2011), 'The multilevel perspective on sustainability transitions: Responses to seven criticism', Environmental Innovation and Societal Transitions, 1, pp. 24-40. https://doi. org/10.1016/j.eist.2011.02.002

GELDERMANS, B., BELLSTEDT, C., FORMATO, E., VARJÚ, V., GRÜNHUT, Z., CERRETA, M., AMENTA, L., INGLESE, P., VAN DER LEER, J. and WANDL, A. (2017), D3.1 Introduction to methodology for integrated spatial, material flow and social analyses, Resource Management in Peri-urban Areas (REPAiR), Horizon2020, European Commission, http://h2020repair. eu/wp-content/uploads/2018/03/Deliverable_3.1_Introduction_to_methodology.pdf

GELDERMANS, B., WANDL, A., STEENMEIJER, M., FURLAN, C., STREEFLAND, T., FORMATO, E., CERRETA, M., AMENTA, L., INGLESE, P., IODICE, S., BERRUTI, G., VARJÚ, V., GRÜNHUT, Z., BODOR, Á., LOVÁSZ, V., MOTICSKA, ZS., TONINI, D. and TAELMAN, S.E. (2018), D3.3 Process model for the two pilot cases: Amsterdam, the Netherlands \& Naples, Italy, Resource Management in Peri-urban Areas (REPAiR), Horizon2020, European Commission, http://h2020repair.eu/wp-content/uploads/2019/11/Deliverable-3.3-Process-model-for-the-two-pilot-cases-Amsterdam-the-Netherlands-and-Naples-Italy-final.pdf

KAIKA, M. and SWYNGEDOUW, E. (2011), 'The Urbanization of Nature: Great Promises, Impasse, and New Beginnings', [in:] BRIDGE, G. and WATSON, S. (eds.), The New Blackwell Companion to the City, Chichester, Wiley-Blackwell, pp. 96-107. https://doi. org/10.1002/9781444395105.ch9

LOORBACH, D. (2010), 'Transition Management for Sustainable Development: A Prescriptive, Complexity-Based Governance Framework', Governance: An International Journal of Policy, Administration, and Institutions, 23 (1), pp. 161-183. https://doi.org/10.1111/j.14680491.2009.01471.x

MUSMECI, L., COMBA, P., FAZZO, L., IAVARONE, I., SALMASSO, S., CONTI, S., MANNO, V. and MINELLI, G. (eds.), (2016), Relazione relativa alle attività affidate all'Istituto Superiore di Sanità, http://docplayer.it/17130506-Relazione-relativa-alle-attivita-affidate-all-istituto-superiore-di-sanita-ex-artt.html. 
OBERSTEG, A., ARLATI, A., ACKE, A., BERRUTI, G., CZAPIEWSKI, K., DĄBROWSKI, M., HEURKENS, E., MEZEI, C., PALESTINO, M.F., VARJÚ, V., WÓJCIK, M. and KNIELING, J. (2019), 'Urban Regions Shifting to Circular Economy: Understanding Challenges for New Ways of Governance', Urban Planning, 4 (3), pp. 19-31. https://doi.org/10.17645/up.v4i3.2158

PALESTINO, M.F. (2015), 'How to put environmental injustice on the planner's radical agenda. Learning on the Land of Fires-Italy', Proceedings of the 29th AESOP Congress on Definite Space - Fuzzy Responsibility, Prague, Czech Republic, July, pp. 2576-2586.

Provincia di Caserta (2012), Il territorio dell'illegalità, Relazione di accompagnamento al Piano Territoriale di Coordinamento Provinciale, pp. 222-233.

STEEN, K. and VAN BEUREN, E. (2017), Urban Living Labs. A living way of working, Amsterdam Institute for Advanced Metropolitan Solutions, Delft University of Technology.

WANDL, A. and MAGONI, M. (2017), 'Sustainable Planning of Peri-Urban Areas: Introduction to the Special Issue', Planning Practice \& Research, 32 (1), pp. 1-3. https://doi.org/10.1080/026 97459.2017.1264191

WITTMAYER, J.M. and LOORBACH, D. (2016), 'Governing Transitions in Cities: Fostering Alternative Ideas, Practices and Social Relations Trough Transition Management', [in:] LOORBACH, D., WITTMAYER, J.M., SHIROYAMA, H., FUJINO, J. and MIZUGUCHI, S. (eds.), Governance of Urban Sustainability Transitions. European and Asian Experiences, Japan, Springer, pp. 13-32. https://doi.org/10.1007/978-4-431-55426-4_2 